\title{
Leger som blir sykehusdirektører
}

\author{
En nylig publisert undersøkelse viser at engelske leger som blir sykehusdirektører er begeistret over \\ å ha en stimulerende jobb som gjør det mulig å bidra til å utvikle helsevesenet. Ingen angrer på karriere- \\ valget. Likevel er det vanskelig å rekruttere leger til utfordrende lederstillinger. Hvorfor?
}

National Health Service (NHS) Institute for Innovation and Improvement har nettopp publisert en kvalitativ studie med dybdeintervju av de 22 legene som er foretaksdirektører (chief executives) i NHS i Storbritannia (1). De 22 legene utgjør bare $5 \%$ av sykehusdirektørene i landet. Bakgrunnen for studien var at NHS har som mål å rekruttere flere leger til topplederstillinger.

Hovedfunnet var at legene er begeistret over å ha en stimulerende jobb som gjør det mulig å bidra til å utvikle helsevesenet, og at ingen angret på karrierevalget. De fleste legene som ble sykehusdirektører, hadde bakgrunn som spesialist og avdelingsleder. Mange hadde vært medisinsk fagsjef før de motiverer og påvirker leger til å kvalifisere seg som toppledere. I Norge fremmer ofte Legeforeningen generalisert kritikk der det hevdes at ledelsen i helseforetakene vektlegger fagligheten for lite, men foreningen differensierer sjelden mellom sykehus med og uten helsefaglig ledelse (2). Foreningen har, i motsetning til for eksempel Norsk sykepleierforbund, ikke utviklet faglige møtesteder for leger i topplederstillinger.

Hvorfor blir leger sjelden ansatt som toppledere i sykehus? Falcone \& Satiani beskriver i en oversiktsartikkel at leger ofte har suksess med ledelse og administrative oppgaver innenfor egen spesialitet, og at man ut fra dette ville forvente at det å ta på seg

\section{«Hvorfor blir leger sjelden ansatt som toppledere i sykehus?»}

ble direktør. Den vanligste motivasjonen var muligheten til å medvirke til en større forskjell for flere pasienter gjennom forbedring av sykehusenes tilbud. Fem (23\%) arbeidet klinisk ved siden av direktørjobben.

Forskerne hadde en hypotese om at leger som blir direktører, endrer selvbilde fra legeidentitet til en lederidentitet. Studien viste imidlertid at direktørene utviklet en hybrid rolleforståelse som utvidet og forsterket den opprinnelige legeidentiteten. De fleste mente at legebakgrunnen styrket deres troverdighet og deres evne til å kommunisere med fagmiljøene, og samtidig gjorde det mulig å utfordre klinikere på en tydelig og kompetent måte.

Legene følte i begrenset grad tilhørighet til sykehusdirektører uten legebakgrunn, og savnet fora som tilsvarer de faglige nettverkene i de medisinske fagmiljøene. Eldre kolleger var de viktigste rådgiverne. Forfatterne foreslår oppretting av et fagmedisinsk forum for å utvikle profesjonell identitet og yrkesutøvelse for leger i direktørstillinger (1).

Utgangspunktet for den engelske studien var at NHS ønsker flere leger som direktører, og man ønsket derfor å kartlegge hva som mer omfattende lederoppgaver ville være en naturlig karriereutvikling (3). Likevel er det bare $3 \%$ av amerikanske sykehusdirektører som har legebakgrunn. Forfatternes litteraturgjennomgang konkluderer med at overgangen fra avdelingsledelse til ledelse av hele sykehuset krever evne til strategisk tenkning, teambygging, kommunikasjon, kritisk tenkning, økonomistyring, endringsledelse og krisehåndtering. Forfatterne mener at manglende trening i strategisk tenkning og økonomistyring er de vanligste årsakene til at leger ikke søker på eller ikke blir funnet kvalifisert til topplederstillinger. I Norge er det grunn til å diskutere om også manglende støtte fra egen fagforening kan være en medvirkende årsak.

Goldman og medarbeidere (4) undersøkte hvilke erfaringer som utvikler evnen til strategisk tenkning, og fant blant annet at god veiledning tidlig i karrieren, erfaring fra stabsfunksjoner, erfaring fra prosjektledelse og jobberfaring fra andre sektorer var viktig. Forfatterne anbefaler at organisasjoner bør ha veiledningsprogrammer og systemer som oppmuntrer til innhenting av erfaringer fra andre virksomheter enn den man selv jobber i til vanlig. Dette kan lett oppnås gjennom jobbrotasjon av leger mellom sykehus og for eksempel regionale helseforetak eller Helsetilsynet, men dette skjer i liten grad.

I Norge er de regionale helseforetakene, på samme måte som NHS, opptatt av å rekruttere leger og andre helsearbeidere til topplederstillinger i sykehusene. Det er sannsynlig at økende krav til kvalitetsstyring vil gjøre kvalifiserte leger mer etterspurte som toppledere. De regionale helseforetakene har i fellesskap etablert Nasjonalt topplederprogram blant annet for å imøtekomme dette behovet. Flere regioner og foretak har samtidig lagt til rette for at leger og andre ansatte kan ta mastergrad i helseledelse. Det er mulig at det i tillegg burde legges bedre til rette for karriereløp som veksler mellom lederog fagspesialiststillinger. Hvis legene skal være med på å sette dagsorden i helsevesenet, er det avgjørende at flere kvalifiserer seg til topplederstillinger.

\section{Tor Ingebrigtsen}

tor.ingebrigtsen@unn.no

Universitetssykehuset Nord-Norge 9038 Tromsø

og

Institutt for klinisk medisin

Det helsevitenskapelige fakultet

Universitetet i Tromsø

Oppgitte interessekonflikter: Ingen

Litteratur

1. Ham C, Clark J, Spurgeon P et al. Medical chief executives in the NHS: Facilitators and barriers to their career progress. NHS Institute for Innovation and Improvement 2010. www.hsmc.bham.ac.uk/ news/pdfs/Medical-Chief-Executives-NHS.pdf (6.9.2010).

2. Janbu T. Kvalitet i sykehus. Tidsskr Nor Legeforen 2010; 130: 187

3. Falcone RE, Satiani B. Physician as hospital chief executive officer. Vasc Endovascular Surg 2008; 42: 88-94.

4. Goldman E, Cahill T, Filho RP. Experiences that develop the ability to think strategically. J Health Manag 2009; 54: 403-16.

Manuskriptet ble mottatt 6.9. 2010 og godkjent 16.9. 2010. Medisinsk redaktør Siri Lunde. 